\title{
A COOPERAÇÃO TÉCNICA TRIANGULAR E O PAPEL DO INMETRO
}

\author{
Leonardo Pace Alves ${ }^{1}$
}

\section{Introdução}

Na atualidade, a Cooperação Técnica Triangular aparece como uma promissora subárea de Cooperação para o Desenvolvimento, unindo os esforços de um país em desenvolvimento e de outro país desenvolvido (ou de uma organização multilateral) em favor de uma terceira nação mais carente de recursos. A Cooperação Técnica Triangular vai ao encontro da oitava meta da Declaração do Milênio das Nações Unidas de 2000, estabelecendo parceria para o desenvolvimento, a fim de reduzir as iniquidades mundiais.

Após permanecer durante duas décadas na condição de receptor do saber técnico das nações mais industrializadas, o Brasil assumiu aos poucos a dupla identidade de receptor e prestador do mesmo, acumulando quarenta anos de experiência na cooperação técnica internacional com os países de menor desenvolvimento relativo. Essa cooperação foi tecida tanto no âmbito bilateral como no trilateral.

Inicialmente, o Brasil fez uso da cooperação técnica triangular como um expediente para enfrentar as limitações orçamentárias em momento de grave dificuldade econômica. No presente, essa parceria triangular ganha características mais complexas, visto que os países em desenvolvimento tendem a desempenhar papel cada vez mais ativo na cooperação técnica à medida que

\footnotetext{
${ }^{1}$ Pesquisador do Inmetro. Mestre em Relações Internacionais pela PUC-RJ e em Estudos Internacionais pela Universidade de Uppsala. Agradeço a Vitor Galiza Xavier pela ajuda na produção do artigo. Este artigo foi escrito a título pessoal e não reflete necessariamente posições oficiais do Inmetro. E-mail: lpalves@inmetro.gov.br
} 
ampliam seu próprio perfil na cena internacional. Nesse contexto, a transmissão do conhecimento técnico passa a ser concebida não só como um meio de cumprir meta onusiana, mas também como um recurso de poder brando (soft power), capaz de aumentar o prestígio desses países na política mundial.

Este artigo visa a analisar a cooperação técnica brasileira, com foco especial no caso da parceria triangular entre Moçambique, Brasil e Alemanha, na qual o Instituto de Metrologia, Qualidade e Tecnologia (Inmetro) encontra-se fortemente envolvido. Assim, apresenta-se um exemplo de Cooperação Triangular não contemplado pela literatura especializada contemporânea. Para tanto, o texto abaixo está dividido em seis itens. No primeiro, descreve-se a evolução da Cooperação Técnica Internacional Norte-Sul; no segundo, examinase a evolução da Cooperação Técnica Internacional Sul-Sul; no terceiro, discutese a Cooperação Técnica Triangular; no quarto, avalia-se o histórico da Cooperação Técnica brasileira; no quinto, analisa-se o Projeto de Cooperação Técnica Triangular Moçambique - Brasil - Alemanha; e, finalmente, expõem-se as considerações finais.

\section{Evolução da Cooperação Técnica Internacional Norte-Sul}

Ao lado da cooperação financeira, da assistência humanitária, da cooperação científico-tecnológica e da ajuda alimentar, a Cooperação Técnica Internacional (CTI) insere-se na categoria abrangente de Cooperação para o Desenvolvimento. Essa cooperação tem como objetivo precípuo superar ou, ao menos, mitigar as assimetrias econômico-sociais que ensejam a divisão entre países desenvolvidos, países em desenvolvimento e países menos desenvolvidos.

Consoante Puente, a CTI pode ser definida como:

"um processo multidisciplinar e multissetorial que envolve, normalmente, um país em desenvolvimento e outro(s) ator(es) internacionais (país ou organização multilateral), os quais trabalham juntos para promover, mediante programas, projetos ou atividades, a disseminação e transferência de conhecimentos, técnicas, experiências bem-sucedidas e tecnologias, com vistas à construção e desenvolvimento de capacidades humanas e institucionais do país em desenvolvimento, despertando-lhe, dessa forma, a necessária autoconfiança que contribua para o alcance do desenvolvimento sustentável, com inclusão social, por meio da gestão e funcionamento eficazes do Estado, do sistema produtivo, da economia e da sociedade em geral." (Puente 2010) 


\section{Leonardo Pace Alves}

A expressão CTI foi, contudo, precedida pelo termo "Assistência Técnica" (AT). Em 1948, mediante a Resolução nº. 200, a Assembleia Geral das Nações Unidas criou esse conceito, com base no qual, aos países desenvolvidos caberia assistir as nações mais desfavorecidas. A partir da década de 1970, no contexto em que os países do terceiro mundo passaram a reivindicar a construção de uma ordem econômica internacional mais igualitária, a AT foi substituída por CTI ou Cooperação Norte-Sul. Essa alteração não era meramente semântica, uma vez que a expressão AT poderia conter a ideia de passividade do receptor ante a caridade da parte do doador. Em contraste, o termo "cooperação técnica" abria a possibilidade de maior intercâmbio construtivo entre o provedor e o recebedor da mesma (Puente 2010). Essa característica da CTI será ainda abordada em mais detalhes no próximo item deste artigo.

Conquanto o discurso da CTI contenha alguns propósitos altruístas vinculados à ideia de promoção do desenvolvimento, existem outros elementos de ordem política, estratégica e econômica que não devem ser desconsiderados. Dessa forma, ao analisar a CTI prestada por um dado país, há que se avaliar não só os princípios e os valores explicitados, mas também os interesses nacionais subjacentes. Isso explica por que a CTI, inicialmente, não foi conduzida com base nas necessidades e nas preferências dos países receptores, mas sim, estribada nas percepções e nos interesses das nações doadoras. Em outras palavras, não raro, ocorreu a "fabricação da demanda" baseada nas prioridades estabelecidas pelos ofertantes da CTI.

Na década de 1980, em meio à grave crise econômica que acometeu as nações periféricas, notadamente na América Latina, alguns países doadores do Norte empreenderam a revisão dos mecanismos de CTI e diminuíram seu volume. Assim, durante a chamada década perdida, observou-se sensível refluxo da CTI, dificultando avanços direcionados para o desenvolvimento. No final dessa década e no início dos anos noventa, esse retrocesso foi acentuado pelo receituário neoliberal do "Consenso de Washington". Dessa maneira, a CTI foi utilizada por algumas nações desenvolvidas como instrumento para estimular a implementação de reformas estruturais nos países periféricos, as quais visavam à diminuição e ao enfraquecimento do Estado. Consoante o credo neoliberal, com o fim da Guerra Fria, o progresso e o crescimento resultariam da livre 
expressão das forças do mercado, em vez da execução de políticas públicas voltadas para o desenvolvimento.

No final de 2008, com a eclosão da crise econômica nos Estados Unidos, a qual se espraiou para outras regiões, afetando atualmente, sobretudo, os países da zona do Euro, o credo do "Consenso de Washington" foi duramente abalado. A intervenção do Estado na economia, com intuito de promover a superação da crise, passou a ser vista como necessária não só nos países periféricos, mas também no epicentro do capitalismo globalizado: os EUA. Nesse contexto turbulento, a CTI ganhou impulso renovado, particularmente em virtude das inovações que já vinham sendo implementadas por alguns países emergentes do Sul no âmbito da cooperação horizontal.

\section{Evolução da Cooperação Técnica Sul-Sul}

A cooperação no eixo Sul-Sul, também denominada de cooperação horizontal, surge como alternativa à tradicional cooperação Norte-Sul ou à cooperação vertical. Nota-se que essa parceria entre os países periféricos não necessariamente deve ser pensada como uma contraposição, já que pode complementar os esforços realizados no eixo Norte-Sul. A cooperação trilateral (abordada no próximo item) ilustra a possibilidade de sinergia entre os dois eixos.

Acresce que, em princípio, a cooperação horizontal resulta de um processo histórico segundo o qual alguns países em desenvolvimento evoluíram, paulatinamente, da simples condição de receptores do conhecimento técnico das nações desenvolvidas para situação dual de prestadores da cooperação Sul-Sul sem, contudo, abdicar por completo dos benefícios advindos da cooperação Norte-Sul. Assim, países emergentes como Brasil, China, Índia passam a ofertar a cooperação técnica no eixo horizontal, ao mesmo tempo em que ainda recebem os dividendos provenientes da cooperação técnica com as nações centrais. Verifica-se, todavia, um gradual declínio do volume de conhecimentos técnicos transferido a esses países pelas nações mais industrializadas à medida que esses emergentes atingem maior grau de desenvolvimento socioeconômico.

Vale a pena aclarar que a cooperação sul-sul pode ser compreendida mediante duas linhas interpretativas, as quais, amiúde, se entrelaçam. De acordo com a concepção até agora descrita, a cooperação horizontal refere-se à 


\section{Leonardo Pace Alves}

definição do Programa das Nações Unidas para o Desenvolvimento (PNUD), segundo a qual se desenvolve a parceria técnica entre os países periféricos. Um segundo entendimento diz respeito à coordenação diplomática entre os países do Sul por intermédio da formação de coalizões políticas de geometria variável (coalition building), visando, entre outras coisas, ao incremento do poder de negociação conjunta em foros multilaterais (Lechini 2010). O Fórum IBAS (Índia, Brasil, África do Sul), o BRICS (Brasil, Rússia, Índia, China e África do Sul) e o G-20 comercial na OMC avultam como exemplos de coalizões políticas, nas quais o Brasil encontra-se inserido.

Duas declarações internacionais são apontadas como alicerces da Cooperação Sul-Sul orientada para o desenvolvimento: a Declaração sobre a Promoção da Paz e da Cooperação Mundiais, acordada durante a Conferência de Bandung, na Indonésia, em 1955, bem como o Plano de Ação de Buenos Aires, formulado durante a Conferência das Nações Unidas sobre Cooperação Técnica entre Países em Desenvolvimento, realizada em Buenos Aires, em 1978 (Zimmermann e Smith 2011).

A Conferência de Bandung foi uma iniciativa das nações afro-asiáticas que haviam logrado recentemente sua emancipação política. Esses países organizaram-se, a fim de opor-se ao neocolonialismo e ao imperialismo das grandes potências no contexto da Guerra Fria. A Declaração que resultou da Conferência ressaltava a necessidade de os países do terceiro mundo reduzirem a dependência econômica dos países centrais mediante a cooperação técnica mútua. Ademais, a Conferência representou um primeiro passo para o futuro lançamento do Movimento dos Países Não-Alinhados, o qual ocorreria na Conferência de Belgrado, em 1961.

Por sua vez, o Plano de Ação de Buenos Aires, advindo da Conferência das Nações Unidas sobre Cooperação Técnica entre Países em Desenvolvimento, foi adotado pela Assembleia Geral das Nações Unidas, em 1978. Esse Plano concorreu efetivamente para o estabelecimento da cooperação técnica horizontal para o desenvolvimento, a qual seria aperfeiçoada nas décadas posteriores. Nesse sentido, designou-se o PNUD como órgão responsável pela coordenação das atividades de Cooperação técnica para o desenvolvimento (Puente 2010).

É digno de destaque que o maior ativismo dos países periféricos, na década de 1970, ocorreu em um contexto de Détente na Guerra Fria. A 
diminuição das tensões entre Estados Unidos e União Soviética facilitou a articulação entre os países do Sul em prol de uma Nova Ordem Econômica Internacional (NOEI). Sombra Saraiva nomeia esse período de "Ilusões Igualitárias". Segundo o autor, os países periféricos julgavam-se capazes de alterar os parâmetros da ordem internacional a seu favor sem, porém, deterem os recursos de poder necessários para alcançar esse desígnio. A grave crise econômica que sobreveio na década seguinte corroborou essa debilidade (Saraiva 2001).

Ainda conforme a visão dos países periféricos, o modelo tradicional de cooperação vertical caracteriza-se pelo assistencialismo permeado por interesses de natureza política, estratégica e comercial. Além disso, eivado de condicionalidades, esse assistencialismo deixa de contemplar as reais prioridades nacionais dos estados receptores, o que leva à perpetuação da dependência ante os países centrais (Puente 2010).

Inversamente, com o intuito de conceder cooperação técnica, países como Brasil, China e Índia não estabelecem condicionalidades no que concerne a aspectos econômicos, ambientais, de governança e de direitos humanos, além de diminuírem os requisitos processuais. Ciosos de sua soberania, em virtude de já haverem sido objeto de ingerências estrangeiras em passado relativamente recente, esses países respeitam o princípio da não interferência nos assuntos internos das demais nações.

Além da preservação da soberania, a ausência de condicionalidades apresenta outras duas vantagens. Em primeiro lugar, proporciona aos países receptores acesso mais rápido ao financiamento dos países emergentes. Em segundo lugar, aumenta o poder de barganha dos países receptores frente à cooperação ofertada pelos países desenvolvidos do Norte, cujas condições costumam ser muito mais severas e inflexíveis (Souza 2012).

Ademais, com base na crítica à nítida assimetria presente no eixo NorteSul, a cooperação técnica no eixo Sul-Sul privilegia os conceitos de parceria, de reciprocidade e de igualdade, os quais imprimem maior legitimidade à cooperação. Conforme a lógica de cooperação horizontal, o desenvolvimento é concebido como um empreendimento coletivo de caráter dialético. Assim, não se trata apenas de um Estado conceder assistência ao outro menos desenvolvido, uma vez que o país ofertante adquire novas experiências que podem ser aplicadas no aprofundamento do seu próprio desenvolvimento (Burges 2012). 


\section{Leonardo Pace Alves}

Outro benefício que advém da dinâmica da cooperação horizontal é a diminuição dos custos existentes. Em geral, países como Brasil e China não contratam consultores externos para seus projetos de cooperação técnica em outros países. Ao contrário, esses países enviam quadros técnicos do próprio governo federal, com o escopo de executar os projetos. Esse procedimento também simplifica a prestação de contas e o monitoramento das atividades empreendidas. Uma vez que os proventos dos técnicos são pagos pelos diversos entes públicos, os gastos reais com a cooperação técnica muitas vezes não entram nos cálculos da agência responsável pela coordenação dos projetos.

Essa dinâmica de cooperação Sul-Sul não está, no entanto, isenta de algumas limitações. Com frequência, os técnicos dos vários entes públicos do governo federal não possuem treinamento específico para aplicar seus conhecimentos à realidade estrangeira em ambiente multicultural deveras distinto. Igualmente, esses técnicos não dispõem da mesma extensão e flexibilidade de tempo de que gozam os consultores independentes estrangeiros para implementar as atividades de cooperação, porquanto a estada no exterior implica a suspensão das tarefas cotidianas nas suas instituições de origem.

Outro ponto bastante sensível é a necessidade constante de responder às críticas internas quanto ao gasto de recursos públicos com a cooperação técnica horizontal. Em função dos graves problemas socioeconômicos ainda enfrentados pelo país doador, faz-se mister justificar por que o dinheiro público é investido na melhoria dos indicadores sociais de outros países desfavorecidos.

Além disso, outro aspecto vulnerável à crítica é o de que a oferta de cooperação técnica sem condicionalidades pode prolongar a permanência de dirigentes corruptos e autoritários que desrespeitam os direitos humanos e o meio ambiente. Essa preocupação é particularmente intensa com respeito às políticas adotadas pela China no continente africano.

A lógica da cooperação técnica horizontal igualmente pode ser relativizada, porquanto, mesmo que a parceria ocorra entre Estados do Sul, haverá uma clara assimetria entre o país ofertante e a nação receptora. Assim, observa-se, ainda, uma hierarquia de poder que matiza a ideia de horizontalidade. Nada obstante, é inegável que a cooperação Sul-Sul aproximase mais do ideal de igualdade entre os dois pólos da equação do que a cooperação Norte-Sul. 
Em suma, malgrado algumas vicissitudes, a cooperação horizontal vem firmando-se como um elemento catalisador de importantes mudanças na ordem internacional pós-Guerra Fria. Em 03 de agosto de 2011, o Secretário Geral das Nações Unidas evidenciou essa constatação no relatório sobre a Cooperação SulSul para o Desenvolvimento:

"South-South interactions are leading to deep changes in the fabric of international relations and have begun to yield a proven development impact, with countries of the South now constituting a powerful force in the global economy." (UN 2011)

\section{A Cooperação Técnica Triangular}

Como analisado anteriormente, a cooperação vertical e a cooperação horizontal não são fenômenos tão recentes. Esta tem suas raízes na década de 1970, ao passo que aquela remonta ao final da década de 1940. Em contraste, a cooperação técnica triangular apresenta-se como um arranjo novo, o qual começa a ganhar relevo na década de 1990.

Em termos gerais, a cooperação técnica triangular pode ser pensada como uma amálgama entre a cooperação vertical e a cooperação horizontal, envolvendo, por conseguinte, um país desenvolvido e uma nação em desenvolvimento, os quais atuam em conjunto, a fim de capacitar tecnicamente um terceiro país do Sul mais carente de recursos.

Ainda que predominante, essa não é o único tipo de dinâmica trilateral possível, já que existe também a cooperação entre dois países do Sul, com o fito de transferir recursos técnicos para outra nação periférica (cooperação apenas horizontal). Há, igualmente, a atuação conjunta entre um país e um organismo internacional em uma outra nação. De todo modo, nesta seção, será abordado apenas o primeiro tipo de cooperação triangular.

Essa modalidade de parceria para o desenvolvimento segue uma lógica de cooperação em cascata (Lechini 2010). Os países periféricos receberam e ainda recebem, embora em menor proporção, os conhecimentos técnicos dos países centrais. Havendo alcançado um nível razoável de desenvolvimento, mediante a adaptação da tecnologia dos países mais industrializados às suas necessidades, esses países periféricos passam a transferir os conhecimentos técnicos tropicalizados às outras nações do Sul. 


\section{Leonardo Pace Alves}

Nesse sentido, os países periféricos possuem a experiência adequada e encontram-se mais bem posicionados do que os Estados centrais para atender às demandas dos seus congêneres do Sul, uma vez que enfrentaram, em passado recente, os mesmos desafios ao desenvolvimento, formulando soluções criativas para aprimorar suas condições socioeconômicas (Ecosoc 2008). Ademais, a cooperação técnica dos países do Sul tende a ser mais bem recebida pelos outros países periféricos, porquanto é desprovida de resquícios da antiga dominação metropolitana.

Com frequência, essa parceria Sul-Sul é marcada, todavia, por dificuldades financeiras do país em desenvolvimento prestador da cooperação. Dessa forma, o financiamento do projeto por um país central torna-se deveras relevante para que o mesmo possa ser realizado (Burges 2012). Daí advém uma das vantagens da cooperação trilateral, pois ao conhecimento técnico e à experiência dos países do Sul soma-se a maior capacidade de financiamento dos países centrais.

A cooperação triangular pode ser, portanto, vista como um arranjo intermediário entre a cooperação no âmbito bilateral e a cooperação no domínio multilateral, congregando, a um só tempo, os esforços de países desenvolvidos e em desenvolvimento em prol do aprimoramento das capacidades técnicas de um terceiro país do Sul (Abneur 2007). Um exemplo de cooperação trilateral da qual o Brasil participa será fornecido mais adiante.

\section{O Histórico da Cooperação Técnica Brasileira}

A cooperação técnica brasileira segue o padrão histórico supracitado com base no qual o país transita aos poucos da qualidade de receptor para a condição de receptor-prestador do conhecimento técnico. Essa evolução desdobrou-se entre as décadas de 1950 e 1970.

Na década de 1950, com o advento da Comissão Nacional de Assistência Técnica (CNAT), vinculada ao Itamaraty, o Brasil passa a planejar-se, a fim de receber a cooperação técnica dos países desenvolvidos. Fazia-se necessário coordenar as demandas das instituições brasileiras por conhecimento técnico, estabelecendo as prioridades, com o intuito de firmar parcerias com os países centrais e as agências das Nações Unidas (Puente 2010). Assim, nas duas décadas seguintes, o Brasil recebeu cooperação técnica principalmente da 
Alemanha, do Canadá, da França, da Grã-Bretanha, da Itália e do Japão, bem como do PNUD (Cervo 2008).

Em 1968, o governo brasileiro criou um sistema de cooperação técnica envolvendo o Ministério do Planejamento e o Ministério das Relações Exteriores. Esse arranjo interministerial assentou as bases para que o Brasil desse os primeiros passos, a partir de 1973, no final do governo Médici, como prestador de cooperação técnica aos países latino-americanos e lusófonos da África (Puente 2010).

Essa orientação aprofundou-se com o Pragmatismo Responsável e Ecumênico do governo Geisel (1974-1979), segundo o qual a política externa foi concebida como instrumento para alavancar o desenvolvimento do país. Em contexto de grave crise do milagre econômico brasileiro, paralelamente ao relativo declínio do poder dos EUA na cena internacional, a presidência de Ernesto Geisel consolidou a tradição global-multilateral da diplomacia brasileira (Leite 2011; Pecequilo 2012). Ao Brasil caberia transpor as fronteiras ideológicas da Guerra Fria, ampliando sua inserção internacional mediante a aproximação com diversos países, notadamente daqueles do então chamado terceiro mundo. Nesse sentido, a cooperação técnica desempenhou relevante papel no adensamento das relações do Brasil com os países em desenvolvimento. $O$ impulso na cooperação Sul-Sul coadunava-se com o Plano de Ação de Buenos Aires de 1978.

A despeito da séria crise econômica que marcou a década de 1980, o governo Sarney logrou dar prosseguimento aos esforços de cooperação técnica horizontal do país, por meio da reforma de sua estrutura institucional, consubstanciada na criação da Agência Brasileira de Cooperação (ABC), em 1987, vinculada ao MRE. Essa reforma emprestou maior dinamismo e flexibilidade à cooperação técnica, a qual favoreceu arranjos triangulares com o Banco Mundial, o BID e o PNUD, entre outras agências multilaterais, como forma de contornar as limitações orçamentárias (Puente 2010). Nota-se que, no ano seguinte, a "cooperação entre os povos para o progresso da humanidade" foi insculpida no artigo quarto da Constituição brasileira como um dos princípios que regem as relações internacionais do país. A cooperação técnica passou, pois, a esposar de maneira conspícua um objetivo de natureza teleológica.

O processo de expansão e de institucionalização da cooperação técnica internacional brasileira manteve-se durante a década de 1990. Em que pese a 


\section{Leonardo Pace Alves}

adoção de políticas neoliberais pelo governo Collor e pelos dois governos Cardoso, as quais implicaram a redução do papel do Estado e a menor ênfase no desenvolvimento, a cooperação horizontal é pensada, cada vez mais, como um instrumento de política externa. Nesse sentido, a escolha dos países com os quais o Brasil cultivou parcerias, visando a transferir conhecimentos técnicos, esteve alinhada às diretrizes diplomáticas.

Assim, durante os dois governos do Presidente Cardoso (1995-2002), priorizou-se a cooperação técnica com os países da América do Sul, no contexto da crescente integração regional. Inversamente, a cooperação com os países africanos foi relegada ao segundo plano, embora alguns projetos hajam sido realizados com as nações lusófonas do continente no âmbito da Comunidade dos Países de Língua Portuguesa. Sombra Saraiva chega mesmo a qualificar os anos noventa como um período de "longa sonolência" nas relações do Brasil com a África (Saraiva 2012).

Nos dois governos do Presidente Lula (2003-2010), a política externa volta a ser intensamente empregada como um instrumento a serviço do desenvolvimento (não só econômico, mas também social). A busca obstinada pela autonomia, mediante a diversificação das parcerias do país no tabuleiro internacional, enseja uma "diplomacia ativa e altiva" (Amorim 2010). Nesse contexto, a cooperação Sul-Sul (nas suas duas concepções) ganha maior proeminência. $O$ incremento das relações com os países do Sul não ocorre, contudo, em detrimento das tradicionais parcerias com as nações do Norte. Ao contrário, esses contatos tendem a reforçar-se como resultado da maior projeção internacional alcançada pelo Brasil.

Além disso, a ênfase nas políticas de redução da pobreza via transferência de renda e a melhora dos indicadores sociais internos conferiu maior legitimidade à cooperação técnica internacional prestada pelo país. De fato, nota-se nítida congruência entre as políticas de inclusão social adotadas no âmbito doméstico e as políticas voltadas para desenvolvimento no plano internacional.

O aumento da cooperação técnica brasileira evidenciou-se, sobretudo, com os países africanos em virtude da alta prioridade atribuída à outra margem do Atlântico Sul pelo governo Lula. Dessa forma, $48 \%$ dos projetos de cooperação técnica coordenados pela $\mathrm{ABC}$ foram direcionados para a África, 
contemplando 36 países. Moçambique, Guiné- Bissau, Cabo Verde, São Tomé e Príncipe e Angola foram as nações africanas que, nessa ordem, mais receberam a transmissão do saber técnico, o que demonstra o foco do Brasil nos países de língua portuguesa (MRE, 2010). Igualmente, Segundo Puente:

"as áreas de maior concentração da cooperação técnica são agropecuária, saúde,
educação e formação profissional, meio ambiente e recursos naturais, administração
pública, energia e biocombustíveis, desenvolvimento social, desenvolvimento
empresarial, tecnologia da informação e governo eletrônico, transportes, indústria,
normalização e metrologia, urbanismo, turismo, defesa civil, entre outros" (Puente
2010).

Acresce que, em oito anos, o Presidente Lula permaneceu 55 dias em solo africano e promoveu a abertura de 17 embaixadas brasileiras. Em termos comerciais, as exportações para o continente africano saltaram de US\$2,9 bilhões para US $\$ 12,2$ bilhões. A nova parceria entre Brasil e África conciliou, portanto, compromisso solidário (baseado em valores altruístas e percepção de uma identidade comum) com interesses econômicos pragmáticos (Saraiva 2012; Valor 2013).

Desde 2011, o atual governo Dilma Rousseff vem aprofundando os laços com o continente africano. Em fevereiro de 2013, a Presidenta participou da III Cúpula América do Sul - África, realizada em Malabo, Guiné Equatorial. A Declaração de Malabo reafirmou o compromisso conjunto de fortalecer os mecanismos de Cooperação Sul-Sul. Recentemente, em maio do mesmo ano, Rousseff esteve presente na Comemoração do Cinquentenário da União Africana, em Adis Abeba, Etiópia. Nessa ocasião, comunicou que seu governo pretende renegociar a dívida de 12 países africanos com o Brasil. Outrossim, anunciou a intenção de criar uma nova agência internacional de cooperação, de comércio e de investimento para a África e América Latina (Valor 2013).

Esse propósito de inaugurar nova agência explicita que a cooperação técnica brasileira não abarca apenas objetivos teleológicos condizentes com o preceito constitucional. Existem também interesses de ordem econômica e política (Puente 2010). Esses distintos objetivos não são excludentes e, na maioria das vezes, estão imbricados. 


\section{Leonardo Pace Alves}

No âmbito econômico, o Brasil elevou consideravelmente o intercâmbio comercial com as demais nações do Sul, reduzindo a dependência com relação aos mercados dos países centrais. Em razão dessa mudança, o Brasil foi menos afetado pelos impactos da crise econômica que se abateu sobre os EUA e, mais adiante, sobre a Europa. Igualmente, ao fomentar a aproximação bilateral com os outros países do Sul, a cooperação técnica vem indiretamente concorrendo para a internacionalização das empresas brasileiras, em especial, na área de serviços.

Uma consequência adversa apontada por alguns críticos é de que a cooperação técnica levaria ao surgimento de competidores potenciais do Brasil em alguns domínios como, por exemplo, na agropecuária e nos biocombustíveis (Puente 2010). Essa possibilidade parece, todavia, ser compensada pelos próprios benefícios oriundos, nas diferentes áreas, da parceria horizontal.

Na esfera política, mediante o adensamento dos liames com o Sul, o Brasil logrou aumentar seu perfil mundial, tornando-se ator imprescindível em diferentes fóruns internacionais. Essa "capacidade de concertação políticodiplomática" afigura-se como um dos mais importantes ativos do país no convívio com as grandes potências, uma vez que, com base na Constituição e na assinatura do TNP, o Brasil abdicou de recorrer à alternativa nuclear como elemento de dissuasão estratégica (Lima 2010). Vale a pena sublinhar que o apoio advindo das parcerias tecidas com os países do Sul mostrou-se fundamental para que José Graziano fosse eleito diretor-geral da FAO, em 2011, e Roberto Azevedo, da OMC, em 2013. Ao ascender a essas duas organizações, é certo que os dois brasileiros continuarão a promover o desenvolvimento como um objetivo essencial a ser alcançado.

Percebe-se, assim, que a cooperação técnica sobressai como relevante instrumento da política externa brasileira, sendo os países africanos um dos principais beneficiários. Em geral, a literatura destaca a atuação da Embrapa, da Fiocruz e do SENAI, respectivamente, nas áreas da agricultura (com a abertura de um escritório em Gana), da saúde (na luta contra a epidemia da AIDS e da Malária) e da educação profissionalizante (Hist, Lima e Pinheiro 2010; Pino 2010; Saraiva 2012). Há, no entanto, outros atores governamentais que também desempenham importante papel na África. 
Cooperação Técnica Triangular Moçambique-Brasil-Alemanha: Fortalecimento Técnico e Institucional do Instituto Nacional de Normalização e Qualidade de Moçambique (INNOQ)

Conforme mencionado acima, a cooperação triangular brasileira principia no final da década de 1980, mediante parceria com agências multilaterais, a fim de fazer frente às dificuldades financeiras domésticas. A partir da década de 1990, o Brasil começa a cooperar com nações desenvolvidas, com o fito de transmitir conhecimento técnico a um terceiro país mais despossuído. Ainda que o governo brasileiro priorize a cooperação bilateral SulSul, a cooperação triangular é concebida como um arranjo complementar que agrega valor à lógica horizontal.

Uma das peculiaridades da cooperação trilateral brasileira é a de que o país amiúde estabelece parcerias com nações das quais já recebeu conhecimento técnico, a fim de fomentar o desenvolvimento de um terceiro país. Assim, nos últimos anos, o Brasil encetou cooperação triangular com o Japão, os Estados Unidos, a Espanha, a Alemanha, a França, a Itália, a Noruega, a Suíça e o Canadá, com o escopo de atuar conjuntamente na América Latina e na África. Ao lado da Organização Internacional do Trabalho (OIT), o Japão destaca-se como o principal parceiro do Brasil na cooperação trilateral (Pino 2012; Souza 2012).

Não obstante os arranjos triangulares envolverem a parceria com países desenvolvidos em prol de uma terceira nação, o Brasil busca manter as características de horizontalidade. Nesse sentido, a cooperação é guiada pela demanda (demand-driven); não são impostas condicionalidades e procura-se transferir boas práticas, adaptando-as à realidade do país receptor.

Consoante Saraiva, na África atual, Moçambique distingue-se como "um caso modelar de inserção internacional altaneira" (Saraiva 2012). Localizado na porção índica do continente africano, o país conquistou sua emancipação política em 1975, mergulhando, no ano seguinte, em uma guerra civil que durou até 1992. Com a democratização, Moçambique iniciou gradual processo de estabilização que engendrou desempenho político satisfatório e equilíbrio macroeconômico. Em 2011, o país atingiu um crescimento do PIB de $7 \%$, apresentando, assim, uma das maiores taxas de crescimento na cena internacional, em um momento de grave crise econômica mundial. 


\section{Leonardo Pace Alves}

Em benefício de Moçambique, a cooperação trilateral voltada para o fortalecimento do INNOQ insere-se no contexto da tradicional parceria entre Brasil e Alemanha na esfera da metrologia. Criado em 1973, o então Instituto Nacional de Metrologia, Normalização e Qualidade Industrial (Inmetro) autarquia federal vinculada ao Ministério do Desenvolvimento, Indústria e Comércio Exterior - recebeu transferência do saber técnico do Instituto Nacional de Metrologia da Alemanha (PTB). Ao longo das décadas de 1970 e 1980, quinze técnicos do Inmetro foram enviados à Alemanha para aprender o idioma e fazer capacitação nos laboratórios do PTB, permanecendo no país em torno de um ano. Durante esse período, tiveram a oportunidade em instruir-se no que havia de mais moderno no domínio da metrologia. Assim, seguindo a dinâmica descrita anteriormente, o Inmetro foi receptor da cooperação técnica antes de passar à condição de prestador da mesma. Com esse objetivo, em 2000, foi criada a Divisão de Cooperação Técnica Internacional (Dicoi), a qual integra a Coordenação-Geral de Articulação Internacional (Caint) do Inmetro.

Por sua vez, a transmissão do conhecimento técnico a Moçambique situa-se no contexto do adensamento das relações do Brasil com a África a partir do governo Lula, particularmente com os países de língua portuguesa. Nota-se que, ainda em 1975, o Brasil foi um dos primeiros países a reconhecer a independência de Moçambique, abrindo uma embaixada em Maputo, no ano seguinte. Em 2003, no início do seu governo, o Presidente Lula visitou o país, assinando onze instrumentos de cooperação técnica.

As bases do intercâmbio entre o Inmetro e o INNOQ são estabelecidas com a assinatura do Acordo de Cooperação e Assistência Técnica de 2007. Conforme o mesmo, as Partes concordaram em cooperar nos campos da Metrologia Legal e Industrial, da Avaliação da Conformidade e da implementação do Acordo sobre Barreiras Técnicas ao Comércio. Esse acordo entre os dois países permaneceu em vigor durante três anos.

Paralelamente, a cooperação trilateral começa a ser esboçada em 2007, por ocasião da missão de prospecção ao Inmetro de dois dirigentes do INNOQ, acompanhados por técnicos da ABC e da GTZ (agência de cooperação internacional alemã). Essa missão visava a identificar a expertise brasileira de interesse do INNOQ para a elaboração de um projeto-piloto de cooperação trilateral. No mesmo ano, foi realizada missão de técnicos do Inmetro, da ABC, 
da GTZ e do PTB ao INNOQ, em Maputo, com objetivo de avaliar as necessidades do Instituto moçambicano.

Com base nessas duas missões, foi elaborado um projeto-piloto, a fim de capacitar institucional e tecnicamente o INNOQ, tornando-o apto a implementar padrões de qualidade nos produtos fabricados e vendidos em Moçambique. Essa qualidade garante a competitividade dos produtos nos mercados interno e externo, além de proporcionar segurança aos consumidores. O projeto foi executado em nove meses com a participação dos cinco atores supracitados. Entre as atividades desenvolvidas, destacam-se:

I. Revisão do Plano Operacional Anual do INNOQ;

II. Apoio ao INNOQ na elaboração de um plano de carreiras;

III. Revisão do Plano estratégico do INNOQ;

IV. Realização de seminário com vistas a divulgar os serviços do INNOQ;

V. Realização de cursos sobre Medição de Massa; Produtos Pré-Medidos; Elaboração de Regulamentos e Estruturação de Mecanismos para Implantação da Metrologia Legal; Medição de Volume; Incerteza de Medição Aplicada à Metrologia Legal; Funcionamento da Avaliação da Conformidade.

O projeto-piloto apresentou três resultados deveras relevantes:

I. Fortalecimento Institucional e Técnico do INNOQ. A estrutura organizacional do Instituto foi atualizada, o que aumentou sua capacidade de ação política e seu reconhecimento dentro do governo e da sociedade moçambicanos. Ademais, a Metrologia Legal principiou a ser implantada nas áreas de massa e de volume (balanças, pesos e bombas medidoras de combustíveis). Foi também elaborado um projeto de legislação para regular a atividade metrológica em Moçambique. A lei de Metrologia foi finalmente aprovada pela Assembleia Nacional em 21 de maio de 2010;

II. Aprendizagem mútua da parte do Brasil e da Alemanha quanto à dinâmica e às potencialidades da parceria entre os dois países, envolvendo a ABC, o Inmetro, a GTZ e o PTB, com objetivo de transmitir conhecimentos técnicos a um terceiro país. Em agosto de 2010, Brasil e Alemanha assinaram Memorando de Entendimento sobre a Cooperação Triangular. Definiram-se os seguintes princípios comuns: apropriação pelo terceiro país (ownership), com base na qual este lidera o processo de implementação do projeto triangular; 


\section{Leonardo Pace Alves}

padrões comuns no planejamento, execução e avaliação dos projetos, bem como divisão igualitária dos custos;

III. Em virtude da avaliação positiva dos três países em relação aos avanços conquistados, foi acordada a continuação da cooperação trilateral em Moçambique, mediante a elaboração de um novo projeto mais ambicioso e abrangente.

Em 2010, Moçambique, Brasil e Alemanha prepararam novo projeto triangular, visando ao "Fortalecimento Técnico e Institucional do INNOQ", com a duração de três anos.

Os três países definiram objetivos específicos em seis domínios:

I. Metrologia: a) serviços de metrologia legal nas áreas de peso, de massa e de volume em âmbito nacional e junto aos Conselhos Municipais; b) serviços de metrologia industrial (temperatura, massa, volume, comprimento, eletricidade, vazão, pressão ou força);

II. Avaliação da conformidade: serviços de certificação de produtos e de sistemas;

III. Normalização: informações às comissões setoriais, de sorte que sejam fixados critérios mínimos de qualidade para produtos nacionais, particularmente quanto a produtos dos setores de alimentos, de agroindústria, de eletrônicos e de construção civil;

IV. Comunicação: plano de comunicação interna e externa (empresas, governo, comunidades e mídia), orientado às metas do plano de negócios;

V. Superação de Barreiras Técnicas ao Comércio: facilitação do acesso dos produtos moçambicanos ao mercado internacional.

VI. Gestão interna.

No que concerne aos atores envolvidos, aos cinco participantes do projeto-piloto (INNOQ, ABC, Inmetro, GTZ e PTB) somaram-se ainda duas outras entidades brasileiras: a ABNT e o INT. Dessa forma, a distribuição das responsabilidades ficou assim definida:

- INNOQ - contrapartida local, provendo o pessoal técnico e o apoio logístico para a execução do projeto; 
- $\mathrm{ABC}$ - coordenação físico-financeira do aporte técnico brasileiro ao projeto triangular.

- Inmetro - execução da contrapartida brasileira no que se refere às metrologias legal e industrial; avaliação da conformidade; certificação de sistemas de gestão bem como superação de barreiras técnicas.

- ABNT - execução da contrapartida brasileira no que diz respeito à normalização.

- INT - execução da contrapartida brasileira no que concerne à certificação de produtos.

- GTZ e PTB - financiamento e execução do aporte técnico alemão nas áreas de Metrologia Industrial, Avaliação da Conformidade, Normalização, Comunicação e Fortalecimento Institucional.

\begin{tabular}{|c|c|c|}
\hline \multicolumn{2}{|c|}{ Quadro Sinóptico Áreas da Cooperação Triangular } & \multirow{2}{*}{$\begin{array}{l}\text { Contraparte } \\
\text { Responsável } \\
\text { Inmetro }\end{array}$} \\
\hline Metrologia & Metrologia Legal (peso, volume e comprimento) & \\
\hline & $\begin{array}{l}\text { Metrologia Industrial (temperatura, massa, } \\
\text { volume, comprimento, eletricidade, vazão, } \\
\text { pressão ou força) }\end{array}$ & $\begin{array}{l}\text { Inmetro } \\
\text { PTB }\end{array}$ \\
\hline \multirow[t]{2}{*}{ Certificação } & $\begin{array}{l}\text { Avaliação da Conformidade - Sistemas da } \\
\text { Gestão da Qualidade }\end{array}$ & $\mathrm{PTB}+\mathrm{ABNT}$ \\
\hline & Certificação de Produtos & $\mathrm{INT}+\mathrm{ABNT}$ \\
\hline Normalização & Normalização & $\mathrm{ABNT}+\mathrm{PTB}$ \\
\hline \multirow[t]{2}{*}{ Comunicação } & Comunicação Institucional e Marketing & GTZ \\
\hline & Comunicação Interna & GTZ \\
\hline $\begin{array}{l}\text { Superação de } \\
\text { Barreiras } \\
\text { Técnicas }\end{array}$ & Acompanhamento junto à $\mathrm{OMC}$ & Inmetro \\
\hline \multirow{5}{*}{$\begin{array}{l}\text { Fortalecimento } \\
\text { Institucional - } \\
\text { Gestão Interna }\end{array}$} & Apoio à adequação da Infraestrutura Física & PTB \\
\hline & Apoio ao processo de acreditação & ABNT \\
\hline & $\begin{array}{l}\text { Rede de comunicação com Conselhos } \\
\text { Municipais }\end{array}$ & GTZ + Inmetro \\
\hline & Plano de Negócios e Plano de Mercado & PTB \\
\hline & Planejamento, monitoramento e avaliação & $\begin{array}{l}\text { GTZ + PTB + } \\
\text { Inmetro + ABC }\end{array}$ \\
\hline
\end{tabular}


Nota-se que, na atualidade, o projeto encontra-se ainda em execução. À guisa de exemplo, serão fornecidos alguns detalhes sobre a implementação, já concluída, na área de Superação de Barreiras Técnicas.

Essa área já estava contemplada pelo supracitado Acordo de Cooperação e Assistência Técnica entre Inmetro e INNOQ. No período de 2007 a 2011, foram realizadas duas missões de técnicos do Inmetro a Moçambique e uma missão de técnicos do INNOQ ao Brasil. Nessas missões, os técnicos dos dois Institutos trocaram informações sobre o funcionamento e as principais atribuições do Ponto Focal (Enquiry Point) do Acordo sobre Barreiras Técnicas ao Comércio da OMC (Acordo TBT). Ressalta-se que tanto o Inmetro como o INNOQ são os Pontos Focais desse acordo, respectivamente, no governo brasileiro e no governo moçambicano. Assim, o Inmetro transmitiu ao INNOQ sua experiência acumulada como Ponto Focal desde 1996.

Vale a pena mencionar que a cada Ponto Focal do Acordo TBT compete precipuamente fornecer informações sobre regulamentos técnicos e procedimentos de avaliação da conformidade de seu país. Em outras palavras, o Ponto Focal atua como centro de referência sobre exigências técnicas do seu país. Desse modo, as informações sobre mudanças nas exigências técnicas de produtos são disseminadas, a fim de evitar potenciais barreiras não tarifárias ao comércio internacional.

Em maio de 2011, dois técnicos da Divisão de Superação de Barreiras Técnicas do Inmetro (Disbt), a qual faz parte da Caint, fizeram uma missão de cinco dias ao INNOQ, em Maputo. Durante esse período, cooperaram com o Instituto para o estabelecimento efetivo do Ponto Focal moçambicano. Para tanto, os técnicos do Inmetro apresentaram os serviços mais atualizados oferecidos pelo Ponto Focal brasileiro (especialmente o "Alerta Exportador!") e firmaram estreita parceria entre os dois Pontos Focais.

Ademais, o Inmetro trabalhou junto com o INNOQ para que fossem identificados os principais órgãos regulamentadores do governo moçambicano, bem como as principais empresas moçambicanas para as quais os serviços do Ponto Focal seriam disponibilizados. Essas iniciativas resultaram na realização de uma reunião com os regulamentadores e de outra com a Associação das Indústrias de Moçambique (AIMO). Deve-se sublinhar que essa articulação com os regulamentadores e o setor privado é fundamental para que o INNOQ possa 
notificar os regulamentos técnicos e procedimentos de avaliação da conformidade à $\mathrm{OMC}$ e estar apto a responder às consultas de interessados nacionais sobre exigências técnicas estrangeiras.

Como resultado mais imediato da missão a Moçambique, o Inmetro ajudou ao INNOQ a dirimir as dúvidas sobre o processo de notificação à $\mathrm{OMC}$, com base nas regras do Acordo TBT. Nesse sentido, os técnicos dos dois institutos revisaram conjuntamente as primeiras notificações do INNOQ, as quais foram enviadas à $\mathrm{OMC}$, em 2012. A cooperação na área de Barreiras Técnicas entre Inmetro e INNOQ redundou, portanto, na participação plena de Moçambique no Comitê de Barreiras Técnicas da OMC na condição de Ponto Focal do Acordo TBT.

Conforme resumido nesta parte, a dinâmica atual da cooperação triangular entre Moçambique, Brasil e Alemanha é bastante complexa, abarcando sete atores e seis áreas de atuação. A descrição da parceria no domínio da superação das Barreiras Técnica ilustrou o relevante papel desempenhado pelo Inmetro em apenas uma das cinco áreas nas quais a autarquia brasileira está envolvida.

\section{Considerações Finais}

A construção de parcerias triangulares deve ser pensada como relevante instrumento, a fim de fomentar a Cooperação para o Desenvolvimento em um período de instabilidade econômica mundial. Ao congregar os esforços de três países com níveis distintos de desenvolvimento, a cooperação triangular potencializa a transferência do conhecimento técnico, reduzindo os custos.

O Brasil vem destacando-se como uma das potências emergentes no campo da cooperação técnica internacional, com o crescente envolvimento de diferentes agências governamentais, o que espelha o grau de excelência alcançado pelas mesmas em diferentes domínios. A presença ativa do país na cooperação técnica tende a aumentar seu poder brando na arena internacional. Como consequência da maior visibilidade desfrutada na política mundial, o Brasil é cada vez mais demandado como ofertante do saber técnico.

O Inmetro insere-se no rol dos atores públicos que têm contribuído para majorar o alcance e o impacto da cooperação técnica brasileira. Com foco no avanço da metrologia bem como na melhoria da qualidade dos produtos e dos 


\section{Leonardo Pace Alves}

serviços, o Instituto provê maior confiança aos consumidores, facilitando o comércio internacional.

O caso da Cooperação entre Moçambique, Brasil e Alemanha demonstra que nesse arranjo triangular não existe uma divisão simplória das tarefas em que um país em desenvolvimento oferta o saber técnico enquanto que outro país desenvolvido apenas financia a iniciativa. Ao contrário, Brasil e Alemanha dividem em igualdade de condições as responsabilidades técnicas, orçamentárias e gerenciais, conferindo a Moçambique a liderança na execução do projeto conforme suas necessidades. Ao fazê-lo, preserva-se a essência da horizontalidade na cooperação técnica, princípio caro às relações internacionais do Brasil. 


\section{REFERÊNCIAS}

Abdneur, Adriana. 2007. "The Strategic Triad: Form and Content in Brazil's Triangular Cooperation Practices". International Affairs Working Paper.

Amorim, Celso. 2010. "Brazilian Foreign Policy under President Lula (20032010): an overview". Revista Brasileira de Política Internacional.

Burges, Sean. 2012. “Desenvolvendo a partir do sul: Cooperação Sul-Sul no Jogo de Desenvolvimento Global". AUSTRAL: Revista Brasileira de Estratégia e Relações Internacionais, 237-263.

Cervo, Amado Luiz. 2008. Inserção Internacional: Formação dos Conceitos Brasileiros. São Paulo: Editora Saraiva.

Ecosoc. 2008. Background study for the development cooperation forum: trends in southsouthand triangular development cooperation. Nova Iorque.

Hirst, Mônica; Lima, Maria Regina Soares; e Letícia Pinheiro. 2010. “A Política Externa Brasileira em tempos de novos horizontes e desafios". Observatório Político Sul-Americano: Análise de Conjuntura.

Lechini, Gladys. 2010. "La Cooperación Sur Sur. Teoría y Práctica. Los casos de Argentina y Brasil en África". Revista Latinoamericana Surmanía, 5779.

Leite, Patrícia Soares. 2011. O Brasil e a Cooperação Sul-Sul em três momentos: os governos Jânio Quadros/João Goulart, Ernesto Geisel e Luiz Inácio Lula da Silva. Brasília: Fundação Alexandre de Gusmão.

Lima, Maria Regina Soares. 2010. "Brasil e polos emergentes do poder mundial: Rússia, Índia, China e África do Sul". In Brasil e os demais Brics Comércio e Política, organizado por Renato Baumann. Brasília: Ipea.

Ministério das Relações Exteriores. 2010. Balanço da Política Externa Brasileira (2003-2010). Brasília.

Pecequilo, Cristina Soreanu. 2012. As Relações Brasil - Estados Unidos. Belo Horizonte: Editora Fino Traço.

Pino Ayllón, Bruno. 2012. "Contribuciones de Brasil al desarrollo internacional: coaliciones emergentes y cooperación Sur-Sur". Revista CIDOB d'Afers Internacionals.

. 2010. La Cooperación de Brasil: un modelo en construcción para una potencia emergente. Madri: Real Instituto Elcano. 


\section{Leonardo Pace Alves}

Puente, C. A. I. 2010. A cooperação técnica horizontal brasileira como instrumento da política externa: a evolução da cooperação técnica com países em desenvolvimento - CTPD - no período 1995-2005. Brasília: Fundação Alexandre de Gusmão.

Saraiva, J. F. S. 2001. Relações Internacionais: dois séculos de história. Brasília: IBRI.

. 2012. África Parceira do Brasil Atlântico: Relações Internacionais do Brasil e da África no Início do Século XXI. Belo Horizonte: Editora Fino Traço.

Souza, André de Mello. 2012. "A cooperação para o desenvolvimento Sul-Sul: os casos do Brasil, da Índia e da China". Cadernos Adenauer.

United Nations General Assembly 66/229. 2011. Report of the Secretary-General: The State of South-South Cooperation. Nova Iorque.

Valor Econômico. 2013. "Em visita, Dilma anuncia nova agência de cooperação para a África". 25 de maio.

. 2013. "Sem companhia Sul-americana, Brasil dobra presença diplomática na África". 27 de maio.

Zimmermann, F., e K. Smith. 2011. "More actors, more money, more ideas for international development co-operation". Journal of International Development.

Websites:

Cooperação Triangular:

$<<$ http://www.abc.gov.br/Projetos/CooperacaoSulSul/CooperacaoTriangular $>>$ Acesso em 02 de junho de 2013. 


\section{RESUMO}

O Brasil destaca-se como uma das potências emergentes no campo da cooperação técnica internacional, com o crescente envolvimento de diferentes agências governamentais. Este artigo analisa a cooperação técnica brasileira, com foco especial no caso da parceria triangular entre Moçambique, Brasil e Alemanha, na qual o Inmetro encontra-se fortemente envolvido.

\section{PALAVRAS-CHAVE}

Relações Sul-Sul; Cooperação Técnica Triangular; Inmetro. 